\title{
大豆グロブリン加熱時の粘性に及ぼす 昇温速度と高温保持の影響
}

\author{
鎌田慶朗* ・梅屋潤一郎**†・木村通秀 ${ }^{* *}$ ・谷井 聡** ・ 山内文男 ${ }^{* *}$
}

\author{
Effects of Heating Rate and High-temperature Holding on \\ Soy Protein Gel Viscosity
}

\author{
Yoshiro Kamata*, Jun-ichiro UMEYA ${ }^{* *} \dagger$, Michihide Kimura** \\ Satoshi TANII ${ }^{* *}$ and Fumio Y AMAUCHI ${ }^{* *}$ \\ * Food Science, Miyagi University of Education, Aramaki-aza-aoba, \\ Aoba-ku, Sendai 980 \\ ${ }^{* *}$ Department of Food Chemistry, Faculty of Agriculture, Tohoku University, \\ 1-1 Tsutsumidori amamiyamati, Aoba-ku, Sendai 981 \\ $\dagger$ Present address: Shiseidou Product Research Laboratories, \\ 1050 Nippa-cho, Kohoku-ku, Yokohama 223
}

\begin{abstract}
Effects of heat treatment methods on soybean globulin gel viscosity were studied. Changes in viscosity during the heat treatment and thixotropic behavior of the samples before and after the heat treatment were studied. $\beta$-Conglycinin became more viscous when a rising rate in temperature was small. On the other hand, the viscosities of glycinin gels did not increase at all at any heating rate, except a case at $35^{\circ} \mathrm{C} / \mathrm{h}$. When the $\beta$-conglycinin solutions were stood at $90^{\circ} \mathrm{C}$ for 20 min during the heating process, their viscosities increased by this treatment and the final viscosities were also higher than those of the samples treated by the standard method. In the case of glycinin, however, the response was more complex. The viscosities increased at low protein concentrations, whereas they sharply dropped after initial small increase in the cooling process at high protein concentrations. These results suggest that the formed gels were destroyed by shear in the viscosity measurements and the destroyed structures were not re-formed in the case of glycinin. It can therefore be presumed that $\beta$-conglycinin gels were formed with non-covelent bonds which is easily restored by standing. On the other hand, glycinin gel network, which seemed to be made up with disulfide bonds, may hardly be recovered by standing.

(Received Jul. 4, 1989)
\end{abstract}

今日，大豆タンパク質は食品用タンパク素材として種々 の用途に使われている．このタンパク質のゲル化特性に ついては種々の優れた研究122) があるが, われわれあ加 熱時の粘性変化という観点からこの性質を追求してき $た^{32 〜 8)}$. 加熱中の大豆タンパク質のゲル形成反応は約 $70^{\circ} \mathrm{C}$ から始まり，加熱中に更に粘度を増加させるが，
主な粘度上昇は冷却過程において生ずる゙3.この粘度上 昇は $\beta$-コングリシニンにおいて著しく，グリシニンは ほとんど変化を示さない3). このことは，通常の静置し ながらつくるゲルにおいて，グリシニンの方が硬いゲル をつくるという報告" と矛盾するように思えた. 一方， $\beta$ アコングリシニンの方が硬いゲルをつくるとの報告 ${ }^{10)}$

* 宮城教育大学家庭科（干980 仙台市青葉区荒巻字青葉）

** 東北大学農学部食糧化学科（干981 仙台市青葉区堤通雨宮町 1-1）

†現在 : 資生堂製品研究所（干223 横浜市港北区新羽町 1050） 


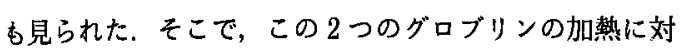
する性質の差を明らかにするため温度環境やタンパク質 隂度を種々変えて粘性上昇に及ぼす影響を検討した。

一方，これら食品用タンパク素材をゲルとして利用す る上で，ゲル特性をコントロールすることは重要な意義 がある.この方法についてはこれまで, 種々の化学的方 法 $^{6111 \sim 14)}$ が試みられてきたが，これらには食品に適用 するには難しいものが多かった，そこで，大豆タンパク 啠のゲル特性をコントロールする方法として物理的手段 が有効と考え，その一方法として加熱ゲル形成時の温度 の状態を変えることにより粘性がどのように変化するか についても検討した.

\section{実 験 方 法}

\section{1. 試．料}

タンパク質試料としては，大豆の主グロブリンである グリシニンと $\beta$ ーコングリシニンを用いた。

これらのグロブリンは，低温においてへキサンで脱脂 した脱脂大豆粉を用い，THANH and SHIBASAKI ${ }^{15)}$ の 方法を用いて抽出分画した。

\section{2. 分散系の調整}

各大豆グロブリンを減圧下でリン酸カリウム緩衝腋 (2.6 $\mathrm{mM} \mathrm{KH}_{2} \mathrm{PO}_{4}, 32.5 \mathrm{mM} \mathrm{K}_{2} \mathrm{HPO}_{4}, 2 \mathrm{mM} \mathrm{NaN}_{3}$, $\mathrm{pH}$ 7.6) に所定のタンパク質濃度（W/V) になるよう 分散させた。

\section{3. 粘度洌定}

粘度測定には共軸円筒回転粘度計（L 型オートビス コメーター，岩本製作所）を用い，内筒之外筒の直径は それぞれ $2.8 \mathrm{~cm}, 3.0 \mathrm{~cm}$ で，浸液長は $7 \mathrm{~cm}$ であっ た. 加熱前のタンパク質-縓衝液分散系, ならびにその 加熱生成ゲルの流動特性を測定する目的で Cyclic shearing test" を行った. まず各測定にあたって，测 定機中で $400 \mathrm{rpm}\left(649.9 \mathrm{~s}^{-1}\right)$ の激しい擋拌を 30 分間 加えて分散系を均一にしてから 30 分間静置し, 分散系 の温度を平衡化させると共に，元の分散状態に回復させ た. 次に温度を $20^{\circ} \mathrm{C}$ に保ち，せん断速度を $30 \mathrm{rpm}$ $\left(48.8 \mathrm{~s}^{-1}\right)$ 加ら $150 \mathrm{rpm}\left(243.6 \mathrm{~s}^{-1}\right)$ まで 10 分間で直 線的に上昇させ，続いて同様に下降させた，この測定を， 以下に述べる Cyclic temperature test の前後に各々 1 回, 計 2 回行った。

加熱 - 冷却過程の構造形成を粘度变化加ら把握する目 的で，加熱処理として Cyclic temperature test 行なった，すなわち，激しい擋汼で初期条件を一定にし， 静置した後，50 rpm $\left(81.2 \mathrm{~s}^{-1}\right)$ の定常せん断変形下で
温度を $20^{\circ} \mathrm{C}$ から $90^{\circ} \mathrm{C}$ まで一定速度で直線的に上昇させ， 続いて同様に下降させた．温度变化速度は， $20^{\circ} \mathrm{C}$ から $90^{\circ} \mathrm{C}$ までを $3 ， 2 ， 1$ 時間と $45 ， 30$ 分で上昇させ，同じ 速度で冷却した．また，温度保持を行う場合は，温度を $90^{\circ} \mathrm{C}$ まで 1 時間で上昇させた後 20 分間その温度を保持 してから下降させた．上記の一連の試験は直接デジタル 制御によって行ない，得られたデータをコンピューター で演算処理した。

\section{結果および考察}

\section{1. 大豆タンパク質の粘性に及ぼす加熱速度の影䇺}

$\beta$-コングリシニンの加熱冷却中の粘度变化が Fig. 1 である。タンパク質嶩度は $12 \%$ であった。一般的に大 豆タンパク質の場合，温度の上昇と共に分散柔の粘度は 低下して行くが, 70〜80 $\mathrm{C}$ のケ化開始温度から急に 立ち上がり, 更に冷却過程において温度の低下と共に粘 度が上昇するという共通の性質を持っている，本実験に よれば，温度上昇速度の遅いもの，すなわちゲル化開始 温度以上に保持された時間の長いあのほど粘性上昇が大 きいことが分かる. 各グラフを対比させてみると，ゲル 化開始点から最高温度までの傾きが最も急で，最高温度 を過ぎるとゆっくりと粘度が上昇している，この様な温

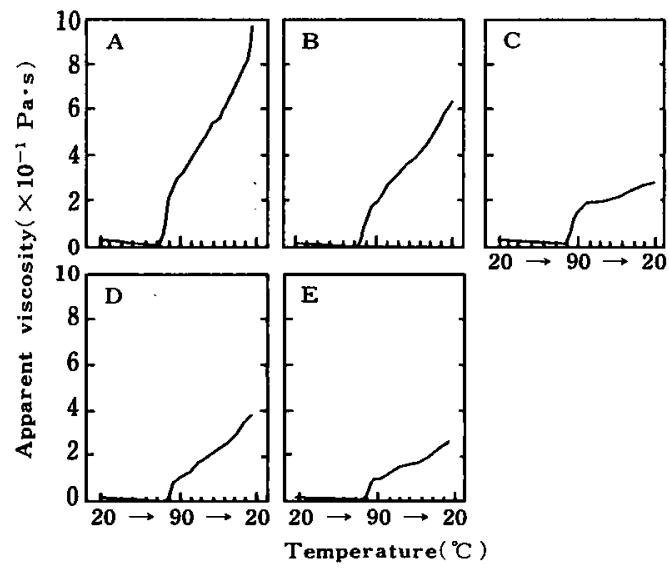

Fig. 1 Effect of heating rate on apparent viscosity of $\beta$-conglycinin-water suspending systems under apparent shear rate of $81.2 \mathrm{sec}^{-1}$ during constant rate heating and cooling process

Heating and cooling rate; $23.3^{\circ} \mathrm{C} / \mathrm{h}$ (A), $35.0^{\circ} \mathrm{C} / \mathrm{h}$ (B), $70.0^{\circ} \mathrm{C} / \mathrm{h}$ (C), $93.3^{\circ} \mathrm{C} / \mathrm{h}$ (D) and $140^{\circ} \mathrm{C} / \mathrm{h}(\mathrm{E})$. 


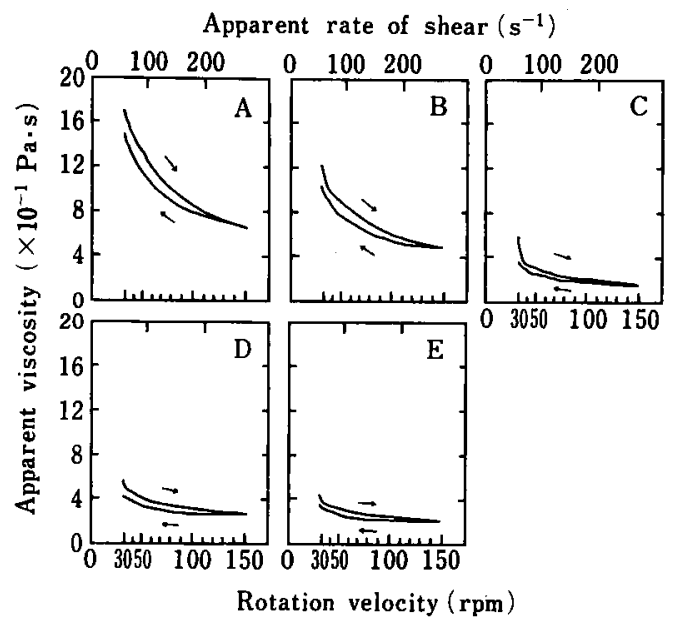

Fig. 2 Effect of heating rate on hysteresis relations between apparent viscosity and apparent rate of shear at $20^{\circ} \mathrm{C}$ of $\beta$-conglycinin thermal gels

Heating and cooling rate; $23.3^{\circ} \mathrm{C} / \mathrm{h}$ (A), $35.0^{\circ} \mathrm{C} / \mathrm{h} \quad(\mathrm{B}), 70.0^{\circ} \mathrm{C} / \mathrm{h} \quad(\mathrm{C}), 93.3^{\circ} \mathrm{C} / \mathrm{h} \quad(\mathrm{D})$ and $140^{\circ} \mathrm{C} / \mathrm{h}(\mathrm{E})$.

度の変化に従って次のようなことが考えられる．すなわ ち，20〜 70 C までは，ゲル化に反映すると考えられる 準構造の形成が起こらず， $70^{\circ} \mathrm{C}$ 付近でタンバク質が変 性を起こすとゲル化が始まる．はじめはほとんど全部が 末変性であるので, 温度の上昇と共に反応速度が上がり, 見かけ上最も急な傾きをつくる，最高温度を過ぎ，プロ グラムが冷却過程に転ずると反応速度す落ちるため，傾 きはやや小さくなるが，この点までに変性したタンパク 質分子が，温度低下と共にとなりの分子と水素結合など を通して準構造を形成しやすくなるために，30〜 40 $\mathrm{C}$ 頃からまた徐々に傾きは急になっていくと考えられる. さらに，ゲルの生成後の Cyclic shearing test におけ る粘性については (Fig. 2), Cyclic temperature test の後, 初期条件を一定にするため激しく擋拌して いるにも関わらず，ゆっくりと加熱したゲルは急速に加 熱したものに対して 4〜5倍の粘性を持ち，30 rpm で の值を比較すると加熱前の約 $0.03 \mathrm{~Pa} \cdot \mathrm{s}$ という值と比 べると, 約 500 倍という高粘度に達することが分かった.

Fig. 3 のグリシニンの場合は, B $\left(35^{\circ} \mathrm{C} / \mathrm{h}\right)$ の試料 の粘性が上杽した他はゲル化の徴候はみられない，これ は， $\beta$-コングリシニンと異なりグリシニンが比較的熱 に安定であるばかりではなく，高濃度でないとゲル形成 反応が進まないためであるとも考えられる．後述の実験

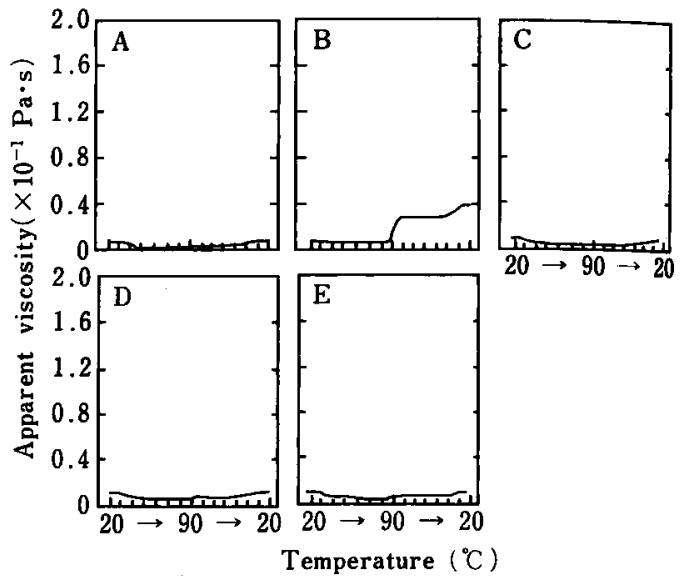

Fig. 3 Effect of heating rate on apparent viscosity of glycinin-water suspending systems under apparent shear rate of $81.2 \mathrm{sec}^{-1}$ during constant rate heating and cooling process

Heating and cooling rate; $23.3^{\circ} \mathrm{C} / \mathrm{h}$ (A), $35.0^{\circ} \mathrm{C} / \mathrm{h}$ (B), $70.0^{\circ} \mathrm{C} / \mathrm{h} \quad(\mathrm{C}), 93.3^{\circ} \mathrm{C} / \mathrm{h}$ (D) and $140^{\circ} \mathrm{C}^{\circ} \mathrm{C} / \mathrm{h}(\mathrm{E})$.

で明らかなように，本実験に用いた $12 \%$ 以下の濃度で はグリシニンは比較的ゲル形成反応が進みにくい，しか し，条件を選べば粘性を上昇させることも可能である. B の場合は, この条件が整ったため上も思われる.

\section{2. 大豆タンパク質の粘性に及ばす高温保持の効果}

前節に述べたように，ある一定温度以上に試料の温度 が保たれている時間が長い方が高い粘性を得ることがで きると考えられる. そこで，このことを確認するため， ゲル化開始温度以上に一定時間保持することを試みた $\left(90^{\circ} \mathrm{C}, 20\right.$ 分間).

$\beta$-コングリシニンの結果を Fig. 4 に示した. 5 段階 の濃度の試料について測定した，各濃度で，温度保持に より見かけの粘度が増加し，この増加分は冷却過程にお いて維持された。例えば，12\%濃度では，保持中に約 $0.2 \mathrm{~Pa} \cdot \mathrm{s}$ 増加し, 冷却過程の最終粘度も保持法による あのの方が $0.2 \mathrm{~Pa} \cdot \mathrm{s}$ 近く高く，両者の曲線はほぼ平 行した. 温度保持中の粘度变化を Fig. 5 に示した. 溜 度が高くなるほど保持中の粘度の増加勾配が大きくなる 傾向にあった．また，保持中にみられた 2〜3 分周期の 粘度の増加減少は, 加熱により形成された構造がせん断 により破壊されたためと思われる. 加熱後の Cyclic shearing test（Fig.6）によると，保持法により生成 されたゲルは標準法によるゲルよりも高いチキソトロピ 


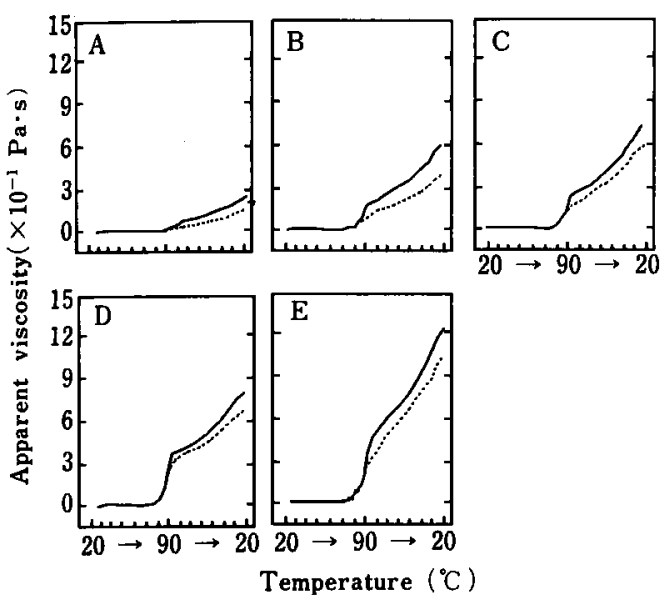

Fig. 4 Apparent viscosity of $\beta$-conglycinin-water suspending systems as a function of temperature with or without temperature holding at $90^{\circ} \mathrm{C}$ for $20 \mathrm{~min}$

Heating rate $; 70^{\circ} \mathrm{C} / \mathrm{h}$

Temperature holding; with $(\longrightarrow$ and without (---).

Protein concentration; $10 \%$ (A), $11 \%$ (B), $12 \%(\mathrm{C}), 13 \%(\mathrm{D})$ and $14 \%(\mathrm{E})$.

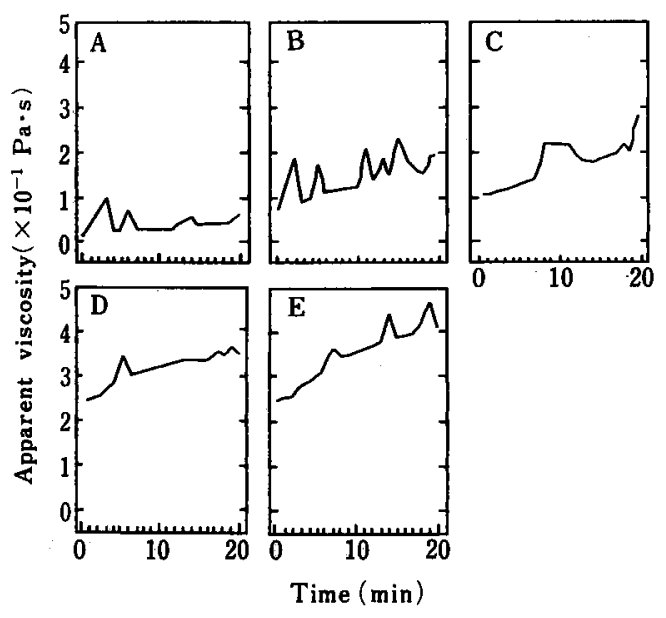

Fig. 5 Change in apparent viscosity of $\beta$ conglycinin-water suspending systems during temperature holding

Heating rate $70^{\circ} \mathrm{C} / \mathrm{h}$

Protein concentration; $10 \%$ (A), 11\% (B), $12 \%(C), 13 \%(D)$ and $14 \%(E)$.

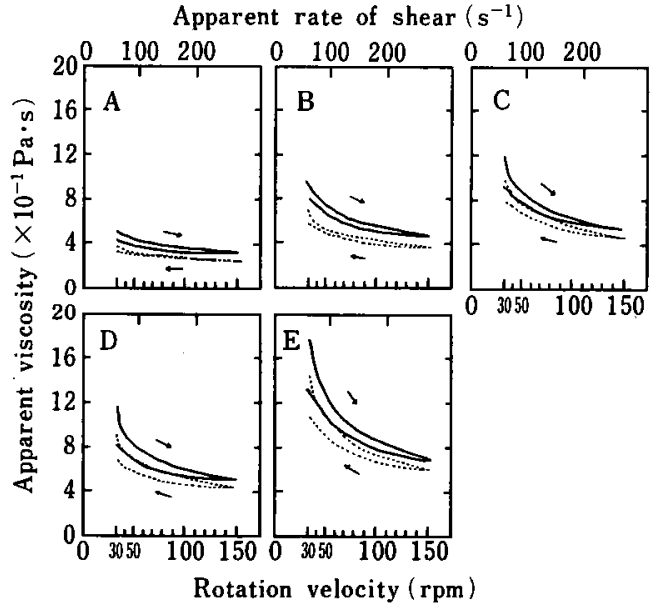

Fig. 6 Effect of temperature holding on hysteresis relations between apparent viscosity and apparent rate of shear at $20^{\circ} \mathrm{C}$ of $\beta$-conglycinin thermal gels

Temperature holding; with $(-)$ and without (---).

Protein concentration; $10 \%$ (A), $11 \%$ (B), $12 \%$ (C), $13 \%$ (D) and 14\% (E).

一性を示し，さらに濃度が大きくなるほど高いチキント ロピー性を示した， $\beta$ ーコングリシニンは，初期設定の ための激しいせん断により破壊されても，静置によって 復元し得る粘性構造を加熱処理過程において生成し，こ の構造形成は高温保持により促進されたと思われる。こ の様に，せん断によって破壊されてあ静䈯によって復元 し，チキソトロピー性の原因となる構造形成は，構造粘 性の一部であり，ゲル形成の一因であるといわれてい $3^{16)}$.

グリシニンの場合の温度保持の効果を Fig. 7 に示す.

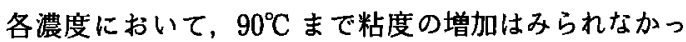
たが， $90^{\circ} \mathrm{C}$ に達し冷却過程に入った後，あるいは保持 過程に入った後に粘度が增加した. $12 \%$ 以下の濃度で は保持法によるものは冷却過程において粘度が増加した が，13\% 以上の濃度ではある程度粘度が上昇した後に， 逆に急激な減少がみられた。これは高濃度において形成 されるゲルの構造が堅く脆いために，世ん断により破壊 され粘度が減少したように見えるためと思われる。

温度保持中の粘度变化を Fig. 8 に示した. $11 \%$ 以上 の濃度において保持中の粘度增加がみられ, 濃度が高い ほどその增加勾配が大きくなった。冷却後の Cyclic 


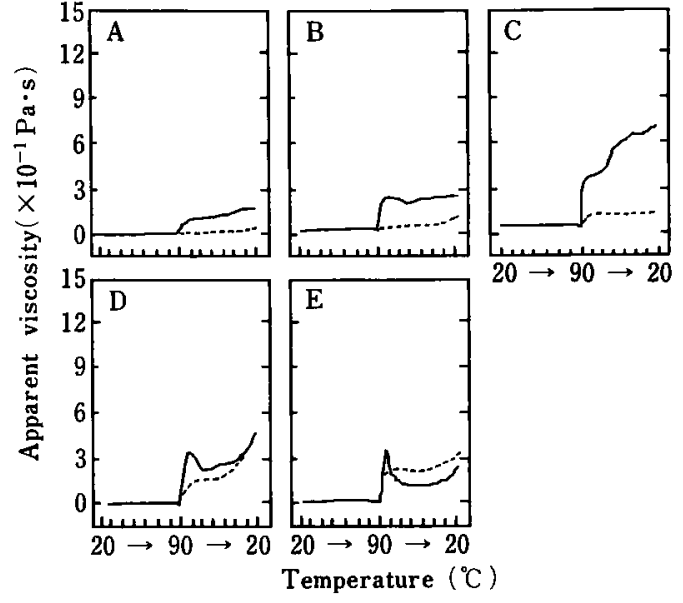

Fig. 7 Apparent viscosity of glycininwater suspending systems as a function of temperature with or without temperature holding at $90^{\circ} \mathrm{C}$ for $20 \mathrm{~min}$

Heating rate; $70^{\circ} \mathrm{C} / \mathrm{h}$

Temperature holding; with $(-)$ and without (---) ,

Protein concentration; $10 \%$ (A), 11\% (B), $12 \%(\mathrm{C}), 13 \%(\mathrm{D})$ and $14 \%(\mathrm{E})$.

shearing test（Fig. 9）によれば，浱度に関わらず温 度保持によって顕著なチキソトロピーを示すようになっ た． $12 \%$ 以下のゲルにおいては濃度の上昇にともない 粘度は增加し，チキットロピー性が高くなり， $90^{\circ} \mathrm{C}$ 保持 により更にその傾向が顕著になった。一方，13\%以上 のゲルにおいては逆に濃度の上昇, $90^{\circ} \mathrm{C}$ 保持により粘度 は隇少し，チキントロピー性も低くなった。これは，冷 却過程において形成されるグリシニンの凝集構造はせん 断により破壊されるが，この構造は 30 分間静置してあ 復元しないためと考えられる。この構造生成は $90^{\circ} \mathrm{C}$ 保 持に上り $13 \%$ 以上の濃度において促進されたと思われ る. $12 \%$ 以下の濃度においても同様の構造形成が行わ れたと思われるが，濃度が低いためせん断により系全体 が破壊されるに至らず，粘度が減少しなかったものと思 われる. Fig. 3 の B の場合も準構造の生成と, 系全体 の破壊のバランスがうまくとれた結果と思われる.

本研究のような回転粘度計による粘度測定は，本質的 に系の破壊を防ぐことができない，つまり，静置して作 ったゲルの粘性を測定することは不可能である.しかし， この方法には，できあがったゲルを観測する他の各種測

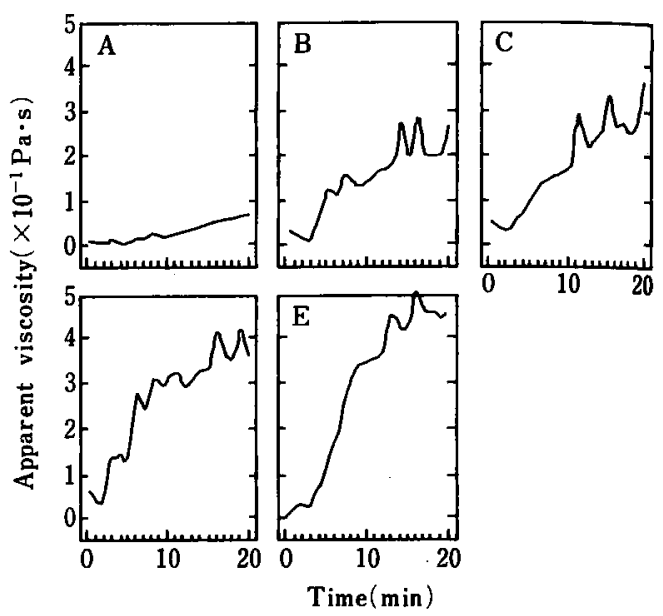

Fig. 8 Change in apparent viscosity of glycinin-water suspending systems during temperature holding

Heating rate $; 70^{\circ} \mathrm{C} / \mathrm{h}$

Protein concentration; $10 \%$ (A), $11 \%$ (B), $12 \%$ (C), $13 \%$ (D) and $14 \%(\mathrm{E})$.

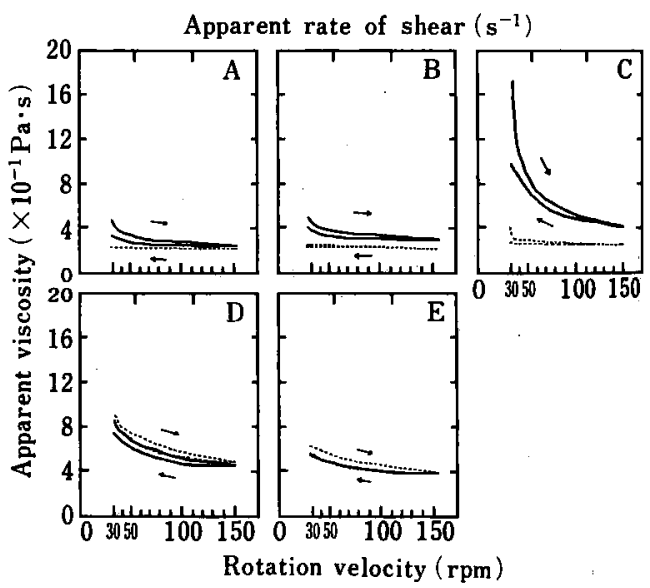

Fig. 9 Effect of temperature holding on hysteresis relations between apparent viscosity and apparent rate of shear at $20^{\circ} \mathrm{C}$ of glycinin thermal gels

Temperature holding; with $(\longrightarrow$ and without (----).

Protein concentration; $10 \%$ (A), $11 \%$ (B), $12 \%$ (C), $13 \%$ (D) and 14\% (E). 
定法にはない，ゲル形成過程を追跡できるという利点が ある. 加熱及び朎却というゲル形成過程は，通常の加熱 ゲルについては共通のプロセスであり，この間に起こる 粘性変化は，本研究のように系の破壊を十分に考慮にい れれば，ゲル形成過程の一つの反映とみることができる 上考えられる。

一方，本実験では加熱冷却後に，生成したゲルに対し て激しい擋神を行い，その後静置して準構造の発達を促 してからチキントロピー性の測定に入っている，この時 の試料は，高粘性を示す場合は，測定機より取り出すと 保形性を示すゲルとなっている，それ故，この時の低回 転速度での粘度は，ゲルのネットワーク構造の強さを反 映しているものと思われる。

本実験で作られたゲルは，チキントロピーを示す。こ れは, Cyclic shearing testにおけるヒステリシスの 存在として定義される ${ }^{16)}$. また，破壊からの構造粘性の 復元す観察されており，大豆のグロブリンのゲル形成に は，復元可能な 3 次元ネットワーク (6) の寄与が大きい 場合があると思われる。この様なチキットロピーを示す システムでの水素結合の重要性肪指摘されている例ああ $ろ^{16)}$.

これまで，グリシニンのゲルと $\beta$-コングリシニンの ゲルの硬さを比較した報告では加熱ゲルについてグリシ ニンの方が硬いものが得られるとしてきたものが多い9. しかし，われわれのこれまでの粘度測定の研究結果 ${ }^{3)}$ で は，グリシニンは加熱冷却後も高粘性を示さなかった。 この結果は，ゲルの硬さについての報告と一見矛盾する ように考えられたが，これは，測定対象の違いに基づく と考えられる.つまり，以上のような考え方に立つと， グリシニンは加熱によりむしろ゙ゲルネットワークを発達 させやすく急速に粘性が上昇するが，このネットワーク は硬いかわりに脆く，せ九断により容易に破壊される。 一方， $\beta$-コングリシニンの場合はそのゲルネットワー クは破壊されても静置すれば容易に復元し, 再び粘度が 上昇する．グリシニンを静置状態で加熱処理すると，粘 度測定のような恒常的なせん断がないため，硬いゲルが 得られることとなる。.この原因としては，グリシニンの ゲル形成にジスルフィド結合のような共有結合が大きな 寄与をしていると報告 ${ }^{17)}$ されているのに対し， $\beta$-コン グリシニンの場合はそのアミノ酸組成にシステインが少 なく、ゲルネットワークの形成には水素結合のような非 共有結合が主な役割を果たしていることによると思われ る.つまり，この様な非共有結合は，力を加えることに より容易に切断されるが，分子レベルにとどまり，結果
は粘度の低下として現れ，系全体が破壊され分断される ことはないので，時間と共に復元することができると思 われる.これに対して，グリシニンゲルの場合は系全体 が破壊され，系としての連続性を失ってしまうものと考 えられる。

\section{要 約}

大豆タンパク質のゲル特性をコントロールする目的で, 加熱時の温度環境を变化させた．試料としては大豆グリ シニンと $\beta$-コングリシニンを用いた，物性の測定は， 加熱中の粘性変化, 加熱前後のチキソトロピー性につい て分析を行なった。

（1）加熱冷却過程における温度上昇下降速度を変える と， $\beta$-コングリシニンの場合はよりゆっくりした速度 の場合に高い粘度を得ることができた，

(2) グリシニンの場合はある特定の速度 $\left(35^{\circ} \mathrm{C} / \mathrm{h}\right)$ の場合粘度が上昇するこ之か観察されたが，他の場合は 顕著な粘度上昇がみられなかった。

(3)加熱冷却処理を行う際に，高温 $\left(90^{\circ} \mathrm{C}\right)$ で一定時間 温度保持を行うと, $\beta$-コングリシニンの場合は濃度に 関わらず粘度を上昇させる効果があり，この効果は冷却 後のゲルの粘性に反映した。

(4) グリシニンの場合は低い濃度で粘度上昇の効果が あったが，蕽度が高くなるとせん断による構造の破壊に よって粘度は下がった。

(5) 以上の結果， $\beta$-コングリシニンの場合のゲル形 成は，破壊されても静置によって復元し得る非共有結合 を主とし，グリシニンの場合は，破壊されると復元でき ないジスルフィド結合を主体としていると推定された。

\section{文献}

1）山内文男: 日食工誌，26，266（1979）.

2) Kinsella, J.E. : J. Am. Oil Chem. Soc., 56, 242 (1979).

3) UmeYa, J., Yamauchi, F. and Shibasaki, K. : Agric. Biol. Chem., 44, 1321 (1980).

4）梅屋潤一郎・山内文男・柴䗁一雄 : 日食工誌，27, 459 (1980).

5) Umeya, J., Yamauchi, F. and Shibasaki, K. : Agric. Biol. Chem., 45, 233 (1981).

6) Umeya, J., Mitsuishi, N., Yamauchi, F. and Shibasaki, K.: Agric. Biol. Chem., 45, 1577 (1981).

7) Miura, M. and Yamauchi, F. : Agric. Biol. Chem., 47, 2217 (1983).

8） 三浦 靖-山内文男: 日食工誌，31，636（1984）. 
9) Saio, K. and Watanabe, T.: J. Texture Studies, 9, 135 (1978).

10) Utsumi, S. and Kinsella, J.E. : J. Food Sci., 50, 1278 (1985).

11）山内文男・菱沼紀子 - 小野秀光・柴崎一雄 : 日食 工誌, 25, 446 (1978).

12) Ochiai-Yanagi, S., Miyauchi, H., Saio, K. and Watanabe, T. : Cereal Chem., 55, 157 (1978).

13) Brinegar, A.C. and Kinsella, J.E. : $J$.
Agric. Food Chem., 28, 818 (1980).

14) Sung, H.Y., Chen, H.J., LiU, T.Y. and Su, J.C. : J. Food Sci., 48, 716 (1983).

15) Thanh, V.H. and Shibasaki, K.: J. Agric. Food Chem., 26, 692 (1978).

16）小野木重治：化学者のためのレオロジー（化学同 人) p. $37,(1982)$.

17）山岸辰則・山内文男：食品の物性 “第 12 集” (食品資材研究会)，p. 117 (1986).

(平成元年 7 月 4 日受理)

\section{新刊紹 介}

Safety of Irradiated Foods

\section{F.F. Diehl 著}

Food Science and Technology シリーズの第 37 巻 である. 食品照射に関する本は何冊かあるが, その安全 性に焦点を较った初めての本である.内容は,

1. 序一歴史

2. 線源及び工程管理

3. 照射の化学効果

4. 照射の生物学効果

5. 照射食品の放射能及び毒性学的安全性

6. 照射食品の微生物学的安全性

7. 照射食品の栄養価

8. 国際機関による照射食品の健全性評価

9. 照射の実用化の現状

10. 各国の許可の現状

11. 消費者運動

CODEX の勧告が付録されており，照射食品の安全性 について，集大成された本である.

$15.6 \mathrm{~cm} \times 23 \mathrm{~cm}, 345$ 頁, 150 ドル Marcel Dekker, Inc.

270 Madison Avenue New York, NY 10016 USA 